\title{
Dominant, Residual, and Emergent: Opposing Forces Hovering over John Dos Passos' U.S.A
}

\author{
Rahmat Ollah Mahtabi (Corresponding author) \\ Department of English Language and Literature, Islamic Azad University, Central Tehran Branch, Iran \\ E-mail: milad.mahtabi@gmail.com \\ Razieh Eslamieh \\ Department of English Language and Literature, Islamic Azad University, Parand Branch, Iran
}

\author{
Received: 01-05- 2015 \\ Accepted: 20-07- 2015 \\ Advance Access Published: August 2015 \\ Published: 01-11- 2015 \\ doi:10.7575/aiac.ijalel.v.4n.6p.166 \\ URL: http://dx.doi.org/10.7575/aiac.ijalel.v.4n.6p.166
}

\begin{abstract}
This study is an attempt to investigate John Dos Passos's U.S.A. Trilogy; The 42 ${ }^{\text {nd }}$ Parallel (1930); 1919 (1932); and The Big Money (1936) in the light of Raymond Williams. Analyzing the trilogy in terms of Williams' hegemonic forces between dominant and emergent, it is recognized that the trilogy is full of tragic lives of characters living in the capitalist society of America. According to what Williams says, there are clashes between cultures in a society. He believes that the dominant culture constantly changes and it would not let other cultures to become the controlling power in the society. This tragedy is not an individual experience, but is rather like a collective consciousness. Each and every character is doing their best to change their condition into better but is opposed by the dominant. This is exactly in line with the idea of Williams that the dominant is able to project its own ideology and way of seeing the world so that the subordinated ones accept it as something natural and common. Although there are different types of hegemony including economic and cultural ones, hegemony in this trilogy is mostly the affirmation of the relations between economic and super-structural aspects of it.
\end{abstract}

Keywords: dominant, emergent, residual

\section{Introduction}

Raymond Williams (1921-1988), was a British cultural critic who provided a political, ideological and social model for the investigation of literature. Williams criticized the traditional views regarding the autonomy of literature and privileged cultural values assumed for literature. He considered literature as a medium for presenting and carrying class values and concerned to establish the changing meanings of the vocabulary used in discussions of culture (Payne \& Rae Barbera, 2010).

In The Long Revolution, published in 1961, Williams develops a broader definition of culture; he defines culture as a way of life. The evolving history of cultural forms and institutions in Britain over the previous 200 years is analyzed and a theoretical framework is developed to explore this process of dynamic change. Williams's concepts of "Structure of Feeling" and Dominant, Residual, and Emergent are developed to explain the ideological negotiations and changing feature of the feeling structures during the time in addition to the dominant and oppositional forms emerged from the change and dynamism. The idea of "Structure of Feeling" is used by Williams to include the whole scope of the society and in an attempt to re-define the three notions of Dominant, Residual, and Emergent. In fact, "Structure of Feeling" refers to a stage before the direct articulation of disagreement against the dominant or hegemony. It is the unconscious feeling and the origin of the emergent (Jung, 2011, p. 607).

"One important conclusion out of this 'keywords' approach is that culture is not understood as a fixed category but a process; it is not a conclusion" (Williams, Marxism and Literature, 1977, p. 295). This idea is developed in Williams's later work Culture (1981). He distinguishes between dominant, residual and emergent cultures, where dominant forms and practices, at any given moment, co-exist with older forms and emergent possibilities which may be absorbed by or challenge the dominant trends. Consequently, once again culture is seen as a complex and dynamic entity rather than an entity with fixed universal values.

Williams believed that one can make general distinctions between different periods of history based on modes of production. These modes of productions are defined as dichotomy of "feudal" and "bourgeois," for example, or "capitalist" and "late capitalist" though these terms and distinctions are too broad and need to be further divided into differentiated moments or points. Accordingly, every point or moment in itself is composed of a process of dynamic contradictory relationships in the interplay of dominant, residual, and emergent forms. This opens up a space to analyze the role that subversive and oppositional identities and movements play within the dominant culture. "Dominant culture is the culture practiced at the present time. What cannot be expressed or verified in terms of the dominant culture are 
lived and practiced in the residual and what comes out of the dominant culture as new meanings and values, new practices and relationships are called emergent"'(Sims, 1994, p. 223-234).

\section{Raymond Williams's Key Concepts about Culture and Power}

The dominant culture in a society refers to the established language, religion, values, rituals, and social customs which are often considered as the norm for the society as a whole. "The dominant culture is usually in the majority and achieves its dominance by controlling social institutions such as communicational systems, educational institutions, artistic expressions, laws, political processes, and businesses" (Marshall, 1998, p. 250).

The dominant perspectives are the most widely practiced ones or the ones practiced by the ruling class. Within the dominant values of any culture, there are many elements of the past, or residual elements, but these elements of the past are filtered--"reinterpreted, diluted, and projected" (Williams, Marxism and Literature, 1977, p. 122) -- so that they can be incorporated into dominant culture. If a residual element is truly oppositional to the dominant, the dominant tries to forget or marginalize it. Sometimes the dominant is successful and sometimes it is not.

The dominant culture is the most powerful, widespread, and influential culture in a society in which multiple cultures exist. Dominance can be achieved by many various means including the economic power and physical force or through more delicate processes of dominance and subordination. The culture that is dominant within a particular region can change over time under the influence of internal or external factors, but it is usually able to reproduce itself effectively from a generation to another. Some societies are made of largely homogenous cultural groups. It means that, despite the status or wealth distinctions within such societies, cultural forces do not reinforce them. Small communities such as tribal societies are usually culturally monolithic. In some cases, one culture becomes the dominant due to the fact that it is the culture of the majority. This type of dominance can lead to a conflict since the dominant culture wants to assimilate smaller cultures while they struggle to survive. For instance, the conflict between Basque and Spanish patriots in Spain illustrates this process. Most of the time, economic power determines the dominant culture since the wealthy class has a great deal of power and its cultural values are supported by their wealth and power (Jameson, 1991).

By residual, it is meant those beliefs, practices, and etc. that are derived from an earlier stage of the society, often very long ago, and which may in fact reflect a very different social formation than the present time. Residual beliefs may remain dominant even after the social conditions that made them dominant disappear (e.g. the common belief that men are inherently more intelligent than or superior to women). Some residual practices may be very old and archaic but their presence is still felt. In other words, residual is what is left from the past. Residual can continue its survival in two ways. It may remain as strong as once it was the dominant norm of the society before or it may only be there as something belonged to the past and a mere symbol of something.

In contrast, Williams states that residual "has been effectively formed in the past, but it is still active in the cultural process, not only as an element of the past, but as an effective element of the present" (Williams, Marxism and Literature, 1977, p. 122). A residual Culture is usually different from the dominant cultures but it may be incorporated into it in practice. In fact, residual incorporation is determined by the dominant culture. It means that, residual should make sense in the areas included by dominant culture (Williams, Culture and Materialism: Selected Essays, 2005). Here, Williams denies the passive role of residual as something belonged to the past and considers a more active role for it. According to him, residual plays an active role in the present time since in practice; it is a part of the dominant norms of the current society. Even more, dominant culture decides and determines the survival or removal of a residual.

"Residual does not exist within or alongside the dominant culture. It operates in a process of continual tension, which can take the form of both incorporation and opposition within it. Residual forms are different from archaic ones in that they are still alive; they have use and relevance within contemporary culture" (Payne \& Rae Barbara, 2010, p. 201). It demonstrates a previous institution or tradition which is still active as a memory in the present, and therefore can reinforce the dominant culture or, on the contrary, it can provide the materials for an alternative or opposition to it. Simply put, residual can take two roles in essence. The first role which can be assumed for it is a form that corresponds to the dominant culture. In fact, it can be a system which acts alongside the dominant and of course according to its rules. The second role it can take is an oppositional or alternative which is a role that takes actions against the dominant. Both of these roles can also be assumed for the emergent which is going to be explained in the next part.

Cultural emergence is based on the creation of real, systematic condition of transformation (De Valle Alcala, 2010) and it breaks the pre-determined limitations of dominance to move forward. The process of emergence, through which an emergent comes into existence, is constantly repeated in alternative and oppositional classes which are straightly limited by the including trade unions, working-class political parties, and working class life styles.

Moreover, emergent cultures also develop in relation to dominant formations, and in practice there is not a clear cut distinction between residual and emergent forms since both of them consist of private or marginalized spheres of experience which the dominant culture initially fails to acknowledge or recognize. For example, new social forces of feminism and green politics challenge both the dominant culture and residual oppositional forms such as the traditional labor movement, yet may themselves base their identities on selective traditions, or on residual notions of nature (Payne \& Rae Barbera, 2010).

Raymond Williams in Culture and Materialism (2005), distinguished between residual and emergent based on the fact that residual includes experiences, meanings and values which cannot be verified in terms of dominant culture but live and are practiced. While, the emergent includes the new meanings and values, practices which are continually being created and there has been, much earlier, a concern to be included in dominant culture. 
Within the dominant, there are also the emergent elements that are considerably alternative to the dominant. These must be distinguished from those novel elements of the dominant. The emergent practices those elements unconsciously developed while the society changes out of a new set of social interactions. They are often very different from the dominant and actively challenge it. They may eventually become dominant themselves, but that is not an inevitable process. The emergent movements usually begin at the margins of a society but become less marginal later. However, this loss of marginality never changes into centrality. That is, the dominant practices were first emergent but it does not mean that all of them could become dominants.

Generally, John Storey (1869-1921) in his Cultural Theory and Popular Culture: An Introduction (1998), asserts that Williams's influential claim that a given social formation consisted of dominant, emergent and residual is on the basis of Fredric Jameson's (1934 to present) claim that postmodernism is the cultural dominant of late or multinational capitalism. That is, Williams claims that the movement from one historical period to another does not usually involve the complete decline of one mode and the establishment of another. Historical changes may simply bring about a shift in the relative place of different cultural modes. In a given social formation, therefore, different cultural modes will exist but only one will be dominant.

The concepts of dominant, residual, and emergent provide a framework for understanding the complex and dynamic ways in which a culture operates as it continuously attempts to maintain stability and balance in the face of everchanging views. While one perspective struggles to be dominant at a given point, the other perspectives also compete to gain dominance. In the following part the key notions of Williams's theories dominant, residual, and emergent will be applied on U.S.A. trilogy to better define the notions and the binary relations between them and explain how they react toward each other.

\section{Dominant, Residual, and Emergent in U.S.A}

John Dos Passos's work entitled U.S.A encompasses three novels: The 42nd Parallel, 1919, and The Big Money. The three novels were originally published together as a single volume. Dos Passos added a prologue entitled U.S.A to the modern edition. Dos Passos uses an experimental technique in the trilogy and incorporates four narrative modes, which include fictional narrative, the camera eye, the newsreels, and biographies and/or historical accounts. Using the fictional narrative technique, Dos Passos tells the life stories of twelve characters living in an American society and in search of a better life.

Mac is a Wobbly and a printer who has problems with women. He also travels about the country and Mexico. He starts off the novel when his family moves to Chicago from Middletown, CT. He is pursuing his dreams to overcome the difficulties in life. So, he moves from a small city to Chicago, a symbol of 'emergent' situation.

Fenian O'Hara McCreary, sit up and take notice and tell us what you think of our proposed removal to the great and growing city of Chicago. Middletown's a terrible bitch of a dump if you ask me . . Meanin' no offense, John ... But Chicago ... Jesus God, man, when you get there you'll think you've been dead and nailed up in a coffin all these years. (Dos Passos, The $42^{\text {nd }}$ Parallel, 2000, p. 11)

Mac learns the printing trade from his radical uncle, who eventually loses his shop partly because of his politics and also because of his drinking. Mac takes off from Chicago and is employed by a confidence bookseller. But the bookseller refuses to give him his wage, so Mac objects to his acts which represent hegemony against Mac who is considered to be counter-hegemony.

'Say, Mr. Bingham, how about my money? It's three weeks now.' Fainy jumped down and went to the horse's head. An expression of gloom passed over Doc Bingham's face.

Oh, lucre, lucre ...

Examine well

His milkwhite hand, the palm is hardly clean

But here and there an ugly smutch appears,

Foh, 'twas a bribe that left it. ...

'I had great plans for a cooperative enterprise that you are spoiling by your youthful haste and greed . . but if you must I'll hand over to you this very night everything due you and more. All right, unhitch the horse and bring me that little package with Maria Monk, and The Popish Plot'. ( Dos Passos, The 42 ${ }^{\text {nd }}$ Parallel, 2000, p. 49)

Mac's narrative is one of the most manifesting ones ascertaining Dos Passos's political views. Mac's narrative is interesting and important for the purpose of the present study because he is the representative of the industrial workers in the early $20^{\text {th }}$ century. He is mostly uneducated but a skillful industrial worker, passionate about the labor movement --the symbol of emergent. However, his ambitions go no further than achieving a happy domestic life. But he has to fight with the difficulties of life to achieve a better situation.

Fainy, you're a bright boy . . . I wish I could have helped you more; you're an O'Hara every inch of you. You read Marx . . . study all you can, remember that you're a rebel by birth and blood ... Don't blame people for 
things . . . Look at that terrible forktongued virago I'm married to; do I blame her? No, I blame the system. And don't ever sell out to the sons of bitches, son. (Dos Passos, The 42nd Parallel, 2000, p. 37)

Mac first experiences the struggle between workers and industry (emergent and dominant) in his childhood when workers at his father's mill decide to go on a strike. The defeat of organized labor is inevitable due to the lack of solidarity between them. But more often than not, the workers are defeated by the hegemonic force (the political society) they are either arrested or denied to work until they can no longer support their families. The situation is worsened by a generally defeatist attitude on the part of the workers. They move against the dominant structure but this does not lead to an emergence. It is nothing but a failure. "Mac's father does nothing upon losing his job except cursing and smoking when his wife and children are forced to work" (Dos Passos, The 42nd Parallel, p. 6). That is, he just verbalizes his opposition to the current condition and does not do anything else.

Jesus God, man, there was nothin' else you could do, was there? What the devil can you do if you haven't any money and haven't any job and a lot o' doctors and undertakers and landlords come round with their bills and you with two children to support? (Dos Passos, The 42nd Parallel, 2000, p. 14)

Despite his movement as a member of working class, Mac's father is in complete surrender and he can just accept the situation while cursing and being dominated. In fact, all the workers of the time are enslaved by the hegemonic system of capitalism. It is best understood when Uncle Tim tells Mac that "an honest working man like John or myself, we can work a hundred years and not leave enough to bury us decent with" (Dos Passos, The 42nd Parallel, p. 10) and the same happens to him as the one who once tried to uphold a strike against the capital system but died and did not leave enough money for his family to bury him. The dominance over their lives is so brutal that the family has to accept it. Their choice to move to Chicago proves this fact. Also, Uncle Tim is Mac's socialist mentor, and Mac's first experience working in the printing shop is for a socialist cause. When Mac is sent to distribute strike handbills, he does a paradigmatic act and finds himself "distracted by spring and the thought of girls" (Dos Passos, The 42nd Parallel, p. 71) which represents the conflict inside a young worker between being dedicated to the socialist and emergent movement or following the routines of life. However, he distributes handbills and ends up being chased by a police officer. Mac's life is somehow a vicious circle. At one moment he is jobless; then finds a job and manages his life. Again and again the capitalist and socialist systems fail Mac and he finds himself homeless and jobless wandering in search of home and a job. Spirit of rootlessness and the pressure of the dominant system are present all through Mac's narrative. His attempts to act as a socialist all fail and at the end there is a fruitless emergent that is just a slight change under the dominant's power.

The other character representing williams's notion is Joe who is Janey Williams's brother. Joe Williams grew up in Washington D.C. Joe as a man from working class who decides to live as a sailor after the death of a friend, during the course of the story has the chance to change his position trying to find a better way of life.

About once a week Joe would get spanked. Popper would come home from the Patent Office where he worked, angry and out of sorts.... Joe seemed to like to provoke him, he'd run whistling through the back hall or clatter up and down stairs making a tremendous racket with his stubtoed iron-plated shoes. Then, Popper would start scolding him and Joe would stand in front of him without saying a word glaring at the floor with bitter blue eyes. .... He'd take down the razorstrop from behind the door and put the boy's head and shoulders under his arm and beat him. Joe would clench his teeth and flush and not say a word and when Popper was tired of beating him they'd look at each other and Joe would be sent up to his room .... and Janey would slip out into the yard with her fists clenched whispering to herself, "I hate him . . . I hate him . . . I hate him. (Dos Passos, 42 ${ }^{\text {nd }}$ Parallel, 2000, p. 137)

As a young boy, Joe got beaten by his father who is a symbol of hegemony for Joe. As a representative of oppositional emergent, Joe would stand in front of him but could do nothing except tolerating his father's anger. So, dominant here cannot be defeated by emergent -Joe. This circumstance in life, for Joe, stands as a residual when he gets older and changes its place with dominant - the current situation in which Joe lives. As a youth, he is in war of movement. Alienated from his own root, he is trying to make himself belonged to a social class (of course the higher one). In most of the sections in 1919, he is wandering on the sea, in port, or trying to get back to the sea.

Joe Williams put on the secondhand suit and dropped his uniform, with a cobblestone wrapped up in it, off the edge of the dock into the muddy water of the basin. It was noon. There was nobody around. He felt bad when he found he didn't have the cigar box with him. Back in the shed he found it where he'd left it. It was a box that had once held Flor de Mayo cigars he'd bought when he was drunk in Guantanamo. (Dos Passos, 1919, 2000, p. 4)

Joe's conflicts start when he blows all his money or knocks some girl up. He can be interpreted as representative of the human condition, alienated from nature by his isolated consciousness, unable to find belongings in any social group or environment. In other words, $\mathrm{He}$ is alienated from the nature (social construct of social order and society), he is faced with structure and order imposed by social classification of capital system. He tried to fight it but he couldn't and then 
became isolated and frustrated. Marriage gives him the way into the upper class. Now he has the necessary devices of dominant in his hand (he has used the legal institution of marriage as way of becoming a member of the dominant group) to act as emergent.

Considering the Williamsian term of dominant and emergent, Joe represents the movement of working class toward getting rid of the persecution by the dominant capitalist system and the traditional view of working class as an inferior one. He fights the dominant in silence but cannot win the war of position. His condition can be assumed an emergent due to the fact that one definition of emergent is to take something to the next level under the surveillance of dominant; not necessarily being an opposition toward dominant. Joe's life condition changes from one to another, apart from the fact that if it is an opposition to the dominant movement or not.

The next character whose life is prominently filled with william's notions of dominant, residual, and emergent is J. Ward Moorehouse. He drives out to his Long Island home with his mistress who is an interior designer from Chicago -Eleanor Stoddard-- to confront his divorce threatening wife. He is in fact in a war of movement to change his position. He tries to hide the truth based on the fact that:

Most of the capital invested in his agency was his mother-in-law's and that she could bankrupt him if she wanted to, which was much worse than a divorce. At that Eleanor felt very cold and crisp and said that she would rather go out of his life entirely than break up his home and that he owed something to his lovely children. J.W. said she was his inspiration and he had to have her in his life and when they got back to Eighth Street they walked back and forth in Eleanor's white glittering drawing- room in the heavy smell of lilies wondering what could be done. (Dos Passos, The $42^{\text {nd }}$ Parallel, 2000, p. 354)

They are together on the eve that America enters the WWI and instead of any fear or confusion, they are filled with excitement. The excitement is the happiness of entering a new way of life and the hope to change the world to live the American way of life. In fact, war for them is a welcome to the world of modernity and getting rid of the old world of residual and dominant. In addition, their fight against the angry wife symbolizes the fight against the dominant. Moorehouse's marriage bond with his wife is the representative of the dominant and hegemonic structure of traditional system. Moorehouse's wife is unable to keep pace with her husband or the world of modernity. Clearly, Dos Passos is signaling a new era (it can be of emergent), not full of excitement and glamor, but of massive, brutal and mindless murder in Europe. However, people such as Moorehouse and Eleanor who are proud of being modern, have no idea what the war will bear. Dominance of American system of values is recklessly moving forward. Also, those people calling for a worker's revolution are just as laughable. Knowing what one may know about the history of labor in America, where characters call for a new emerging order, gives one the feeling that nearly everyone in the novel is profoundly out of touch with the state of the country and the world. This ironic backdrop is the reason why the working class disappointment with their politics is so shocking. In fact, here a duality is presented; a dominant system (America) wants to change the world using its 'political society', while an emergent movement (working-class) is trying to change the dominant system. Again, the 'political society' is exercised by the dominant.

Richard Ellsworth Savage is the representation of emergent. He seeks freedom of speech, bravely expresses his idea and fights for his right to take the message of peace and freedom to America. His being emergent is practiced through his cultural capital (language skill and general charisma) to fight and infiltrate the dominance of upper class. However, it is revealed that there is no resistance to the authority exercised on him; it is all consent. Even later, Richard became the member of a dominant group, the Army.

General Sykes was a little old man with bright eyes and a hawk nose and extremely deaf. Yes, Ellsworth was a great fellow, we campaigned against Hieronimo together . . . Ah, the old west . . I was only fourteen at Gettysburg and damme I don't think he was there at all. (Dos Passos, 1919, 2000, p. 349)

There, he practices his skill with language (the cultural device instead of the political society of williams) to exercise authority. A person who has been in favor of the emergent oppositional movement now exercises the hegemonic dominant.

\section{Conclusion}

U.S.A. trilogy is the actual representation of the conflict of two cultures; dominant on one side and emergent on the other. The narrative recaptures the dynamisms and confusions of early twentieth-century America when the people of working class were trying to emerge as a new society on the ashes of the tired dominance. The trilogy hosts characters coming from various social classes with different intentions of changing and surviving in their lives such as Mac, Joe, and Richard Ellsworth Savage interweaving their destinies and making their ambitions and frustrations a part of the social fabric. However, in the mutual interaction between the characters as the symbols of emergent and American system as representative of the dominant, the former are the losers. In fact, their struggle to find a position never ends as a new dominant. The rises and declines of these restless people is a matter of mere opposition or what Antonio Gramsci calls counter-hegemony.

Williams argues that emergent culture defies the dominant system. In different stages in his life, Mac confronts barriers on his way to change his current laborious situation but he meets failure in his every attempt. So, according to what Williams says, Mac represents an emergent movement which is just an oppositional one that cannot lead to a new 
dominant mode and remains as a mere oppositional emergent. Like Mac, Joe and Richard have ups and downs in their lives. They suffer from disruption and upheaval in their lives and wander around in search of an ideal life they would never be granted. Joe's confrontation with his father in his early life can be considered as a Williamsian representation of a dominant-emergent tensions in which the father subjugates his son. This domestic subordination and its harsh effects in his early stages of life, encourages him to fight for a better life as an independent individual and defy any kind of subordination to a dominant mode. For Moorehouse, Marriage is a symbol of dominant which does not let him to have freedom of being with another woman out of marriage bond. He is acting against the dominant mode by having a love affair with another woman. He is also trying to suppress his wife and consequently the marriage bond between them to have a new -emergent-- life with a new bond with another woman. Discussing the abovementioned examples in the fictional life stories of characters presented in U.S.A tries to state that in all stages of life in all periods of history, there is a constant clash and tension between all same-mode entities e.g history, literature, politics, and etc.

\section{References}

De Valle Alcala, R. (2010). Towards Cultural Materialism: Criticism and, hegemony in Raymond Williams. Estudios Ingleses de la Universidad Complutense, pp. 67-76.

Jameson, F. (1991). Postmodernism or, the Cultural Logic of Late Capitalism. Duke University Press Books.

Jung, Y. (2011). The Concept of "Structure of Feeling” According to R. Williams and the Stratification of Classoriented Labor Movements in Contemporary Japan: A Case Study on 'A' local union in Tokyo. Linköping University Electronic Press.

Marshall, G. (1998). A Dictionary of Sociology. London: Oxford University Press.

Payne, M. \& Rae Barbara, J. (2010). A Dictionary of Cultural and Critical Theory (2nd ed.). Willey-Blackwell: Library of Congress.

Sims, R. L. (1994). Dominant, Residual, and Emergent: Recent Criticism on Colombian Literature and Gabriel Garcia Marquez. Latin American Research Review, pp. 223-235.

Storey, J. (1998). Cultural Theory and Popular Culture: An Introduction (2nd ed.). Athens: University of Georgia Press.

Williams, R. (1977). Marxism and Literature. New York: Oxford University Press.

Williams, R. (2005). Culture and Materialism: Selected Essays. UK: Verso. 